\title{
Rating and rewarding Higher Education for Sustainable Development research within the marketised higher education context: experiences from English universities
}

\author{
Sophie E. F. Bessant and Zoe P. Robinson \\ Environmental Education Research
}

\author{
Dr Sophie Bessant, Academic Developer - corresponding author \\ Keele Institute for Innovation and Teaching Excellence \\ 59/60 The Covert, Keele University, Staffordshire, ST5 5BG, United Kingdom \\ 01782 733518, s.e.f.bessant@keele.ac.uk, OrcidID: orcid.org/0000-0002-5735-5764
}

Biography: Sophie is an Academic Developer based within Keele University's Institute for Innovation and Teaching Excellence, working to support academic staff across the university through a range of teaching and learning CPD programmes, workshops and consultancy. Prior to this role, Sophie worked as a Sustainability Project Officer in the School of Geography, Geology and the Environment, undertaking Higher Education for Sustainable Development (HESD) focused research and teaching activities. Sophie completed her PhD at Keele in 2017 which, broadly speaking, explored different roles and purposes of Higher Education (HE) in England and the extent to which different roles and purposes of the university are in tension (or not) with one another. More specifically, Sophie's empirical research investigated how increasing marketisation in English HE has influenced the pursuit, practice and development of HESD agendas within England's HE sector since the mid-2000s, exploring a range of contradictions/challenges, as well as synergies/opportunities presented to HESD agendas and research, within the prevailing marketised context. Prior to joining Keele, Sophie studied at The University of Nottingham from 2004 to 2008, graduating with a BSc Hons Degree in Geography and an MSc in Environmental Management.

Dr Zoe Robinson, Reader in Geography and Sustainability, Director of Education for Sustainability School of Geography, Geology and the Environment William Smith Building, Keele University, Staffordshire, ST5 5BG, United Kingdom 01782 734303, z.p.robinson@keele.ac.uk, OrcidID: orcid.org/0000-0002-9499-264X

Biography: Zoe is a Reader in Geography and Sustainability in the School of Geography, Geology and the Environment, and Keele University's Director of Education for Sustainability. Zoe has extensive experience as a sustainability education practitioner, having developed and run an undergraduate programme in Environment \& Sustainability for almost ten years, as well as supporting other staff to embed sustainability in their own teaching. Zoe has worked in an advisory capacity in the area of Education for Sustainable Development (ESD) for the Higher Education Academy, National Union of Students, and the Environmental Association for Universities and Colleges. Zoe has a broad background in sustainability-related research, spanning the natural and social sciences, with a special focus on ESD. Zoe's work covers student perceptions of environmental citizenship, activist learning for sustainability, energy reduction through community knowledge networks, through to groundwater in glacial environments. Zoe ran an environmental education group for nine years, working with a wide range of schools, colleges and local county councils, to deliver environmental education programmes. Zoe's work has been funded by the Natural Environment Research Council, 
Economic and Social Research Council, Engineering and Physical Sciences Research Council, the Department for the Environment, Food and Rural Affairs, amongst others. 


\section{Rating and rewarding Higher Education for Sustainable Development research within the marketised higher education context: experiences from English universities}

This paper explores one key aspect of marketisation in English universities, the quality-related research funding (QR) system, which central government in the United Kingdom uses to allocate funds to Higher Education Institutions (HEIs), based on a system of reviewing and rating the 'quality' of research at different HEIs. Specifically, it focuses on the experiences of thirty members of academic staff from eight universities across England who were engaged in research and/or scholarly activity in the broad field of Higher Education for Sustainable Development (HESD), during the time leading up to the 2014 Research Excellence Framework (REF) submission period. Interviewees were asked to talk about their experiences of being a HESD researcher/scholar within the context of the QR system and their perceptions of the relationship between the QR system and interdisciplinary, sustainability, pedagogic and HESD research. Findings from the semistructured interviews and resulting qualitative analysis, reveal a number of obstacles facing HESD researchers which are outlined and explored in the paper. Strategies and rationale for improving the quality, reputation and ultimately, the 'REF-ability' of HESD research are discussed, and highlight the complex interface between marketisation and sustainability in higher education.

Keywords: education for sustainable development, higher education, research excellence framework, quality-related research funding, marketisation

\section{'Marketisation' in English Universities}

The term 'Marketisation' was first used in relation to Higher Education (HE) in the mid-1990s and describes the deliberate exposure of Higher Education Institutions (HEIs) to competitive marketbased mechanisms and forces (Williams 1995; 1997; 2016). A recent definition defines marketisation, in the higher education context, as: '...the attempt to put the provision of higher education on a market basis, where the demand and supply of student education, academic research and other university activities are balanced through the price mechanism' (Brown 2015, 5). The instrumentalist economic view of higher education perpetuated by marketisation regimes, whereby universities are conceptualised first and foremost as drivers of national economic competitiveness, has been part of a much broader privatisation and marketisation trend that has shaped all corners of public services in the United Kingdom (UK) since the 1980s. This trend has also been mirrored in countries such as the United States of America, New Zealand and Australia, who have experienced similar market-based transformations to their national higher education systems (Kogan and Hanney 2000; Olssen and Peters 2005; McArthur 2011; Brown and Carasso 2013).

Higher Education marketisation is underpinned by Neoliberal ideology and New Public Management practices. Neoliberalism is a political-economic ideology and policy model based upon the principles of economic liberalisation and decentralisation, that is, a reduction in government intervention and regulation in relation to the national economy, paving the way for an increased role of the private sector in a more market-oriented economy (Giroux 2002; Brenner, Peck and Theodore 2010; Hursh, Henderson and Greenwood 2015). The way in which theoretically neoliberal governmental regimes, i.e. that espouse a free economy and a decentralised state, in fact rely heavily on steering, manipulation and regulation of market conditions in order to create 'self-interested individuals' and promote 'free market economics', has been the subject of much debate and discussion over the last 30 years (Gamble 1988; Middleton 2000; Hursh, et al., 2015). It is this centralised state control of the public sector within the neoliberal climate that is commonly known as New Public Management 
(NPM) (Gruening 2001). NPM is a process whereby competitive, private-sector management discourse, is deliberately mobilised by government within public services, such as universities, in an attempt to improve the 'efficiency, effectiveness and excellence' of such services (Deem 2001, 10; Chandler, Barry and Clark 2002; Deem and Brehony 2005; Ferlie, et al. 2008). Taken together, Neoliberalism and NPM underpin the essence of the marketised university, characterised by audit, accountability, quality assurance regimes, multiple modes of publicly reported measures of performance, and a focus on outputs and impact, all of which have significantly enhanced competition between HEls, academic departments and individual academic staff in recent decades (Kogan and Hanney 2000; Brown and Carasso 2013).

Since the 'Browne Review' (Browne 2010) of HE funding and student finance in England in 2010, which raised undergraduate student tuition fees from $£ 3000$ to $£ 9000$ per year (fees were first introduced in 1997 at $£ 1125$ per year and raised to $£ 3000$ in $2006^{1}$ ), England's HE sector, which accounts for over $80 \%$ of the UK's HE income and student population, has entered a heightened period of marketisation. As well as the introduction of tuition fees of $£ 9000$ per year (with inflationary increases since this time), this recent amplification of marketisation is exemplified by the introduction of the Teaching Excellence and Student Outcomes Framework (or TEF) in 2016 (to assess the quality of undergraduate teaching via a gold, silver, bronze rating scale) and, the creation of the Office for Students (OfS) ${ }^{2}$ in 2018, all of which are championing a 'student as consumer' narrative and are putting ever-growing pressure on academic departments and HEls, to compete for students and provide value for money (Ferudi 2011; Foskett 2011; McCaig 2011; Brown 2015).

\section{The relationship between Marketisation, Higher Education for Sustainable Development and HESD research}

Higher Education for Sustainable Development (HESD) is a term which captures the long-standing 'sustainability agenda' of universities around the world, with a particular emphasis on Education for Sustainable Development (ESD), while also drawing upon the wider policies, politics and epistemologies, which shape the trajectory of the HE sustainability movement (Barth et al. 2016; Lotz-Sisitka 2016). ESD has been defined by the UK's Quality Assurance Agency (QAA) as '...the process of equipping students with the knowledge and understanding, skills and attributes needed to work and live in a way that safeguards environmental, social and economic wellbeing, both in the present and for future generations' (QAA 2014, 5). There is long standing critique of neoliberal marketisation within the mainstream HESD literature. Such critique, which ranges from implicit to explicit, moderate to extreme, is embedded within many calls from HESD writers for radical and transformative change away from current educational ideologies. For Sterling, a key advocate of this transformative vision, sustainability has never been 'just another issue' to be added to already over-

\footnotetext{
${ }^{1}$ Over the time that tuition fees have been progressively increased, the direct teaching block grant to HEls from central government has been progressively reduced, meaning that tuition fees have become an increasingly large proportion of HEls' income, hence why competition for students has increased.

${ }^{2}$ The Office for Students (OfS) is the independent regulator of HE providers in England, which has four main stated aims, to: help students get into and succeed in HE; help students stay informed about their HE choices; make sure that students get a high-quality education that prepares them for the future; and, protect students' interests and deliver value for money for students (OfS 2018, 1).
} 
crowded curricula, but is '... a gateway to a different view of curriculum, of pedagogy, of organisational change, of policy and particularly of ethos' (Sterling 2004a, 50).

For many HESD theorists, and particularly the more critical and radical environmental and sustainability education writers, neoliberal market-based forces are the fundamental barrier facing educational communities, including universities, in their quest to support and drive forward social, environmental and sustainability-based 'public-goods' for society, people and the planet (Irwin 2007; Blewitt 2012; McKenzie 2012; Hursh, et al. 2015; Gonzalez-Gaudiano 2016). As Kopnina $(2016,140)$ describes: 'Various critical environmental educators and more radical proponents of ESD identify the 'enemy' as a capitalist neoliberalism'. Indeed, within the more critical and radical HESD literature (like those cited here), ideals about how education and universities need to be reformed in order to progress a more socially and environmentally sustainable future, and marketisation ideals about how education and universities need to be reformed in order to progress a more economically competitive future, are portrayed as an incontrovertible paradigmatic and ideological contradiction.

Though there is much work which explores the theoretical and ideological relationship between neoliberal marketisation and environmental and sustainability agendas, both within and beyond academia, it is also important that we understand the practical manifestation of this relationship when thinking about how best to progress and grow sustainability agendas in universities. HESD research is inherently interdisciplinary, sustainability-focused and often pedagogical, ranging from the macro level of HESD epistemology, politics and policy, to the meso level of university HESD approaches, strategies and systems, to the micro level of classroom practice and pedagogy. Highquality, published HESD research is an important component of the broader HESD field, not only for disseminating sustainability education ideas, approaches and methodologies, but also for raising the status and profile of HESD activity and HESD research, as valuable and respected avenues of scholarly activity within marketised university regimes. Ultimately HESD activity drives HESD research and in turn HESD research provides a robust evidence base for HESD activity. This paper provides a practical exploration of the complex relationship and interface between marketisation and HESD, via the UK's quality-related research funding system, which is just one of many marketbased transformations to UK HE that have taken place since the early 1980 s.

\section{Introduction to the UK's quality-related research funding system}

Governmental financial support for research in all UK-based HEls (England, Wales, Scotland and Northern Ireland) is distributed via a dual support system. This dual support system distinguishes between annual 'core funding' from UK central government which is provided for research facilities and infrastructure and is allocated based upon the outcomes of the UK's quality-related research funding (QR) system, and 'additional funding' for specific research projects, which until recently came from the UK's seven Research Councils. The UK's QR system was first introduced in 1986 to apportion government funding for research to HEls, based upon the assessed quality of the research being undertaken at different universities, whilst also taking into account the volume and relative cost of research in different subject areas. This audit of research quality is carried out at the scale of Units of Assessment (UoA) which are based loosely around specific discipline areas. There are currently thirty-four UoAs split over four main research panels. 
These research quality audits, which have been carried out in 1986, 1989, 1992, 1996, 2001, 2008 and 2014, were known formerly as the Research Assessment Exercise (RAE) and, since 2012, the Research Excellence Framework (REF) and have been coordinated until 2018 by the (recently disbanded) Higher Education Funding Council for England (HEFCE). Going forward the REF will now be coordinated by a new body, Research England, itself part of a new UK sector-wide body UK Research and Innovation (UKRI). UKRI also subsumes the seven previous research councils, meaning that both streams of the dual support structure, now formally sit within the same research funding body. Other sources of research income within universities for specific research projects, include charities, local authorities, health/hospital authorities, industry and European Union sources, amongst others.

\section{The impact of the QR system on universities and their staff}

Several studies have explored the impact of the UK's quality-related research funding system on universities and their staff, expressing concern from the outset about its deleterious, 'competitive, adversarial and punitive spirit' (Elton 2000, 274). Some studies provide detailed accounts of the technical evolution of the RAE/REF over time, tracking changes in university and academic behaviours in response to these changes (Barker 2007; Marques et al. 2017); others provide more focused analyses of particular elements of the system, e.g. the complexities associated with the assessment of journal article quality (Bence and Oppenheim 2003). There are studies which explore the intricacies of funding selectivity and the concentration of research funding in the highest-rated departments and HEls (Adams and Gurney 2010), and more recently, the merits and pitfalls of the research 'impact' agenda ${ }^{3}$ have received attention (McNay 2015; Watermeyer 2016). Overall, most studies depict the creation of a system which is deeply imbued with power dynamics governing which types of knowledge and research are 'valuable' and 'valued', and through which incentives have been created for HEls and academic staff to follow certain research directions at the expense of others in order to optimise QR funding and esteem. Studies focused on QR have described the privileging of research activities over teaching in universities (including in promotions and appointments) which the system has helped to encourage; strategic game playing in research activity; a narrowing and alignment of research to fit the parameters of the RAE/REF; as well as, the privileging of disciplinary over interdisciplinary research, internationally-applicable over nationallyrelevant research, shorter-term over longer-term research, and, top rated journal outputs over all other types of publication (Harley 2002; Lucas 2006; Alldred and Miller 2007; McNay 2003; 2015; Adams and Gurney 2010; Harland et al. 2010; Oancea 2010; 2014).

\section{The impacts of QR on HESD and higher education pedagogical research}

Relatively few studies have undertaken detailed qualitative analyses of academic staffs' experiences of the QR system; even fewer have focused on the experiences of HESD and HE pedagogical researchers. A recently commissioned research project by the UK's Higher Education Academy (HEA) was one of the first to explore HE pedagogical research in the context of the QR system, asking

\footnotetext{
${ }^{3}$ Research impact agenda: In the 2014 REF exercise, measurement of 'research impact' - defined as: '...an effect on, change or benefit to the economy, society, culture, public policy or services, health, the environment or quality of life, beyond academia' (HEFCE 2016,1) - was incorporated alongside measures of 'research outputs' and 'research environment' for the first time (replacing the previous measure of 'research esteem').
} 
whether pedagogical research is 'the Cinderella of academia' (Kneale, Cotton and Miller 2016; Cotton, Miller and Kneale 2017). Through a desk-based study and semi-structured interviews, this study found that HE pedagogic research faces myriad barriers in terms of credibility and QR recognition, which start with the internal sifting procedures undertaken by HEls when collating research to be submitted to the Research Excellence Framework. These barriers included that HE pedagogic research does not always meet the perceived quality threshold in terms of sample size and theoretical underpinnings; that those responsible for coordinating submissions to the Education Unit of Assessment (UOA 25) do not always fully understand HE pedagogic research; as well as HE pedagogic researchers, who are often spread across HEls, being regularly overlooked, either purposively or through lack of awareness, by schools of education compiling REF submissions. Underrepresentation of HE pedagogic research in the 2014 REF was confirmed in the post-REF report produced by REF Main Panel C (where the Education UoA resides) which describes how: 'Although prepared for such work, the sub-panel assessed only a small number of submissions related to teaching and learning in various subjects within universities and colleges' (HEFCE 2015, 110). Building from this important study, the research presented here represents the first empirical study to focus on the experiences of HESD researchers/scholars specifically, in relation to the UK Research Excellence Framework, set within the broader context of HE marketisation.

\section{Methodology}

This paper presents one of twelve core analytical themes from a broader doctoral study conducted part-time between 2011 and 2017, which aimed to explore the relationship between marketisation and HESD in English higher education. The time lag between data collection and completion of this paper is a result of this overall thesis timescale. The research design for the doctoral study, was a sector-wide 'macro level' case study of HESD in English HE (see Figure 1). Case study research focuses on exploring the complexities and uniqueness of contemporary social phenomena within their real-life contexts (Simons 2009; Kyburz-Graber 2016) and as such, this case study sought to holistically characterise England's HESD agenda within the context of marketisation.

The embedded ${ }^{4}$ case study, consisted of two principle subunits of analysis, whose work overlaps in the context of HESD: 1) Higher education bodies and organisations with a sustainability/ESD remit and sustainability/ESD-active staff; and, 2) Higher education institutions with a sustainability/ESD remit and sustainability/ESD-active staff. Given the macro-level focus of the case study, a selection of $\mathrm{HE}$ bodies and a selection of $\mathrm{HE}$ institutions were sampled, and within these a selection of individuals, to take part in the research via semi-structured interviews. HE institutions and HE bodies were sampled purposively, i.e. for theoretical and targeted purposes, based upon known characteristics related to their HESD activities (Arber 2011). As della Porta (2008) notes, caseoriented researchers most often select 'positive' cases to research, where the phenomena under investigation are clearly evident, in order to provide a valid and challenging test of the research objectives.

Figure 1 - Conceptualisation of the doctoral case study research design [to be inserted here]

\footnotetext{
${ }^{4}$ An embedded case study is one where the overall case contains multiple embedded subunits of analysis, whereas a holistic case study is a more comprehensive entity which is not carved up into subunits (Yin 2003).
} 
A complex screening exercise consisting of multiple levels of analysis, categorisation and elimination was employed in order to select how many and which HEls to sample. In brief, a shortlist of twentysix universities both strategically committed to sustainability/HESD and also performing well across a broad range of sustainability/HESD indicators, was produced from an overall list of the 129 publicly funded HEls in England in the year 2013/14. This shortlist was developed through analysis of each university's corporate documentation, as well as using sustainability/HESD performance metrics from the People and Planet Green League Table 20135. From this shortlist, two universities from each of the UK's four principal university mission groups/types were sampled in order to draw upon different experiences of, and insights in to, marketisation. The final eight universities for the doctoral study thus included: two Russell Group; two Research Led; two Former Polytechnic; and, two New Universities (see Table 1, Appendix, for further explanation about these categories). Data for the full thesis was collected via fifty-four semi-structured interviews with individuals spanning the two core subunits of analysis; twelve interviewees came from across the five sector bodies and forty-two from the HEls. The thirty interviewees represented in this paper are those from the HEls that were actively engaged in research and/or scholarly activity in the area of HESD. A summary of interviewees by professional category, academic title and institution type is summarized in Table 2 .

It is important to note that the interviewees came from a range of background disciplinary areas, as is the case with many HESD researchers/scholars. Furthermore, the engagement of interviewees with HESD research/scholarship activities, ranged from individuals that were fully immersed in HESD as their primary academic activity, to individuals who had a dual focus on HESD research alongside their core disciplinary research, as well as some individuals who had a more recent interest in HESD. Interviewees were asked the following four questions about their HESD research, alongside a range of other questions about different aspects of HESD in the context of marketisation. Their answers to these four questions form the data set used in this paper.

1. What types of sustainability and/or HESD research activities are you involved with and how are these funded?

2. What are the main factors which govern your own personal research strategy and how you prioritise new research projects?

3. Does the quality-related research funding system (i.e. the RAE/REF) influence your pursuit of sustainability and/or HESD research in any ways?

4. To what extent do you believe that the quality-related research funding system (i.e. the RAE/REF) accommodates and recognises interdisciplinary, sustainability, pedagogic and HESD research (recognising that many were engaged in research which crossed a number of these categorisations)?

Twenty-four interviews were carried out face-to-face in the participants' place of work, six were carried out over the phone, between September 2013 and June 2014. Interviews were audio recorded and transcribed professionally. Before any data collection commenced the research project was reviewed and approved by Keele University's Ethical Review Panel. All participants were

\footnotetext{
${ }^{5}$ The People and Planet Green League, now known as the People and Planet 'University League', is the only UK-based publicly available league table which rates and compares all HEls based upon the same selection of sustainability-related performance criteria. For this doctoral study, HEls scoring either a 2:1 or 1st class award overall and either two or three out of three on the 'Education and Learning' criteria, were selected.
} 
provided with a detailed information sheet and consent form, which they were asked to read and sign to ensure informed consent to take part in the research. All data used in the presentation of this research has been fully anonymised.

\section{Table 2 - Number of interviewees by professional category, academic title and institution type} represented in this paper [to be inserted here]

\section{Theoretical framework and data analysis}

Interview transcripts were coded and analysed using a bespoke theoretical framework, which, in contrast with the broadly Critical Theory tradition of HESD research, combined tenets of Pragmatist theoretical perspective, with Constructionist/Interpretivist theoretical perspective, between which there are obvious commonalities (Goldkuhl 2012). Pragmatism is a theoretical tradition rooted in empiricism, rather than philosophy; it rejects metaphysical disputes and ideological dichotomies in search of useful and workable ideas, policies and 'ways forward' (Crotty 1998; Goldkuhl 2012; Morgan 2014; Lohse 2017). Although theoretical and methodological blurring in research has been subject to critique, including within HESD specifically (Dillon and Wals 2016), the pragmatist theoretical tradition, through its evasion of philosophy (West 1989), actually encourages pluralism (both ontologically, epistemologically and methodologically). This research thus sought primarily to explore the practical, day-to-day manifestation of HESD/HESD research within the context of England's marketised university system and to generate practical strategies for the ongoing development of HESD/HESD research agendas, rather than perpetuating well-rehearsed critical analyses of the neoliberalisation of UK HE.

All interview transcripts were analysed using a manual process of Descriptive and Focused Coding (Saldana 2009). This overall process involved three stages as follows: 1 ) verbatim passages of text from the interview transcripts, known as the 'descriptive codes', were assigned interpretive 'analytic codes', in line with the aims and objectives of the doctoral study and the theoretical framework; 2) repeating and analogous descriptive and analytic codes were grouped together in to broader 'key themes' and in turn, broader overarching 'core themes' of the data; 3 ) key and core themes were reanalysed and reorganized several times to produce a coherent thematic analysis expressing the data corpus of the PhD as a whole (Cope 2003; Saldana 2009). In the overall doctoral study there were several hundred analytic codes, which were built into forty-three key themes of analysis, which were in turn, built into twelve overarching core themes. 'Quality-related research funding and HESD' was one of the twelve doctoral core themes, which itself, comprised seven key themes of analysis; three of these related to the general impacts of the QR system and four related to the impacts of the QR system on interdisciplinary, sustainability, pedagogic and HESD research.

\section{Results Theme 1: general impacts of the quality-related research funding system}

The three sub-themes of analysis related to the general impacts of the QR system were: 1) a view of the QR system as elitist, self-perpetuating and disciplinary focussed; 2 ) description about the links between $Q R$ recognition and academic and institutional reputation, prestige, and status; and 3) anxiety and stress caused by the QR system.

\section{QR as an elitist and self-perpetuating disciplinary-focused system}


Like previous analyses in this area, interviewees described the QR system as a self-perpetuating disciplinary-focused system, which they said, encourages staff to research and publish within disciplinary confines and whose rules are determined by elite disciplinary communities from the highest ranking universities. As one interviewee described:

'...the whole apparatus of the REF, schools, universities, they're all configured along disciplinary lines. The national REF panel, which is established of senior academics in the discipline, are people from the higher ranking universities, making sure that the parameters are set that they benefit [from]. And that's the problem, you only reach the top of your discipline and get selected for these panels if you're doing that kind of research which is more disciplinary focused...'

Within this disciplinary-focused system interviewees described hidden, as well as more explicit, sets of rules about what and where to publish, with each discipline having top-rated journals, which academics felt forced to submit to. Interviewees detailed:

'I have to work very hard to make sure the papers that I publish are in the right journals, which are all Geography journals. I have to publish in those if I want to keep my job'

'Here the business academics have been told they must concentrate on getting four star papers and four star journals; recognised Business journals. You'll do what is required to get that Academic Chair within a Business School'

'Top research gets published in a handful of really highly regarded journals which publish very, very mainstream stuff. [Not publishing in these journals] it's kind of academic suicide because it's considered, you may as well just write an article in the Guardian newspaper'

'There were only two metrics that mattered, research income brought in and quality of your journal outputs'

Changes to QR funding allocation methodologies introduced in 2014 were described as further enhancing this elitism. In particular, the move to only provide funding for $3^{*}$ and $4^{*}$ rated research where previously $2 *$ rated research had also received funding ${ }^{6}$.

\section{Links to academic and institutional reputation, prestige and status}

This pressure to publish high-quality disciplinary research in the 'correct journals' was linked by several interviewees to their academic reputation, prestige and status within the university, as well as their job security and promotion opportunities (as seen in several of the quotations above). Interviewees described fears around 'getting booted out first' and being 'pushed to the margins' for not being 'REF-able'. The impact of QR on the reputation and league table standing of universities was also discussed, as was the way in which QR shapes and steers many different activities at the individual, departmental and institutional level, as university staff strategically game-play seeking to

\footnotetext{
${ }^{6}$ REF Research Star Ratings: 4* and 3* research are classed as 'world-leading' and 'internationally-excellent' respectively. $2^{*}$ research, which no longer receives funding as part of the $\mathrm{REF}$, is classed as 'recognised internationally'. $1 *$ research is 'recognised nationally' and there is also an 'unclassified' category.
} 
maximize the kudos bestowed by the REF system. Interestingly several interviewees emphasized the importance of REF for bringing in university income, despite the fact that only $16 \%$ of university funding in the UK comes from QR funding, whereas $54 \%$ comes from teaching funding from government and student tuition fees combined (UUK 2016). Quotes from interviewees which emphasized these points included:

'REF is important; departments stay open or closed, get refigured on that basis. People don't keep their jobs because they're great at outreach, they keep them because they're good at research'

'...it impacts on not just the research, the teaching, the collegiality within the department, everything is driven by the REF. The university's status in the world and the nation is largely driven by the REF'

'People know what is valued, and what is valued by the university is largely what's valued by the REF because that determines our status and our income'

'All research is done with an eye on what can be submitted now to REF and to RAE previously'

\section{Anxiety and stress caused by QR}

Another linked theme was the angst and stress caused by the pressure to publish high-quality research in high-quality journals, with interviewees describing the QR system as 'a curse', 'evil' and 'stifling'. Interviewees also detailed the knock-on impact QR has on collegiality. For example, interviewees stated:

'REF pushes us towards being very, very conscious all the time about your research, it makes you very sensitive, because you're always sitting there thinking, have I produced enough? Am I producing good quality? Am I doing this right?'

'It really increases angst for those academics who are so bound up in their work and their research, and their publications sort of validates their identity. It's really divisive for departments, and lots of people get quite miserable about it. So as an exercise I think it's well designed to create disharmony, dissatisfaction and disillusionment'

\section{Results Theme 2: Impacts of the quality-related research funding system on interdisciplinary, sustainability, pedagogic and HESD research}

Overwhelmingly interviewees detailed how interdisciplinary, sustainability, pedagogic and HESD research are not well recognised or accommodated by the QR system. Three sub-themes in this vein related to: 1) a perceived systematic lack of recognition of interdisciplinary research within QR; 2) interviewees experiences of being actively discouraged from pursuing HESD and pedagogical research; and, 3) perceived issues with the quality of HESD journals. The fourth sub-theme relates to the responses of a small number of interviewees (a minority in the study overall) who had a more positive story to tell about their experiences of the REF and HESD research. 


\section{Systemic lack of recognition of interdisciplinary research in the QR system}

The first sub-theme relates to the systemic lack of recognition of interdisciplinary research in the $Q R$ system and, in particular, sustainability research, which is by its nature interdisciplinary, which interviewees felt was penalised by the discipline-based panels. A few interviewee responses included:

[QR] will recognize very focused areas that align very well with traditional subjects. But if you're doing research on sustainability which is doing that really difficult thing of synthesizing input from quite a few different disciplines, I think it can really struggle to get significant recognition'

'There is a problem with the REF and that's to do with interdisciplinarity. I did this great project which brought lots of disciplines together, but there is no way I could feature that book in the RAE/REF because its different disciplines; it wouldn't have fitted anywhere'

'REF is not very fit for purpose really if you were looking at sustainability, because it is a discipline driven assessment; encourages a silo mentality culture of working in a discipline and I think that's very problematic'

Some interviewees depicted a situation where they felt they were 'cutting across boundaries' of disciplinary areas and in particular, 'falling between the cracks' of RAE/REF panels and thus having to make hard choices (often promoted by line managers) about what to focus their research efforts on and as one interviewee described, about whether to 'jump one way or the other'. This situation is however at odds with the strong emphasis placed on interdisciplinary research from the UK Research Councils (as part of UKRI), which does not match up with the disciplinary focus of the REF.

One interviewee who was a REF panel member described how interdisciplinary research is 'routinely disadvantaged' by the QR system, saying: '...it's quite difficult for truly cross-disciplinary research, to be well received either by funders or by assessors because there aren't any experts. You're almost, by definition, on the boundaries of everyone's expertise, so you don't fit in the heart of anything...' Although the REF has a system of cross-referrals for papers which cut across the boundaries of two or more different UoAs, this interviewee described how these papers never get appropriately considered by either the panel they are initially submitted to, nor the one they are referred to. Other interviewees also expressed mistrust with the paper cross-referral system.

\section{Active discouragement of HESD and pedagogical research}

Focusing on HESD and pedagogical research more specifically, several interviewees described a situation whereby they are encouraged by their departments to focus on writing and submitting to the REF their core background disciplinary research and that they are actively discouraged from writing and submitting HESD and teaching and learning-focused papers, which are not seen as 'REFable'. One key issue here is that disciplinary Units of Assessment (UoAs) do not readily consider pedagogical research, HESD-focused or otherwise, within the confines of the discipline. Although there are a variety of highly ranked disciplinary-based journals which do focus on higher educationand pedagogic research, notably in Law (e.g. The Law Teacher), Geography (e.g. the Journal of Geography in Higher Education) and Medicine (e.g. Medical Education), and are accepted by 
discipline-based REF panels, not all discipline areas have similar pedagogic journals, and furthermore, papers published in journals such as these, will not automatically be put forward for institutional REF submission. This is because most university departments tend to bring together groups of papers for submission based around core discipline-based themes and it is often harder for small numbers of pedagogic articles to fit within these broader narratives. Interviewees said:

'If someone's got six papers, two of which are ESD and four are more mainstream to the panel, you would de-risk the situation by taking the four that are mainstream'

'For the REF you would go into a subject area group, the publications that you would do in the teaching area, wouldn't go into the REF...'

'You know not to put it [ESD research] in the Environmental Science UoA, because it simply isn't the main hard core research they would expect, but it doesn't naturally fit into the Educational UoA either, unless it's absolutely pure hard mainstream pedagogic research'

'It's not something that's hugely encouraged [pedagogical research], mainly because a lot of people think it's not REF-able, because it couldn't go into a Chemistry submission'

'I don't see how I am going to be submitted in the next REF, and that's seven years of paper writing ahead of me - first author papers around sustainability education - because they won't fit within any Geography or Earth and Environmental Science Unit of Assessment'

I had a struggle to make the case that when I did research on teaching and learning that that was actually within Geography. I wasn't put forward... ...I didn't have enough Geography and I didn't have enough what was considered to be Education'

'What wouldn't be valuable or valued, is if I wrote a paper on 'education' for SD, or if I reflected on the school practice or my teaching, that's the kind of thing that isn't REFable'

\section{Perceived quality issues with HESD journals}

A compounding issue described by interviewees was the perceived calibre of journals in which HESD articles are routinely published, which do not always align with the elite disciplinary expectations of the REF panels. Interviewees described these journals as the 'lower ranking echelons' and not having a 'high enough esteem'. By the same token, the high-ranking journals which are welcomed by the REF panels were described as not accepting of interdisciplinary sustainability or HESD articles leaving HESD research in a seeming no-man's land.

\section{When $Q R$ is not a problem}

There were a handful of individuals from across the range of universities who did not perceive the REF to be a barrier to their HESD research. These included staff working in departments that were not submitting to the REF in 2014 and so had more flexibility with their personal research; latercareer staff no longer striving for promotions; and, a few members of staff in the two New Universities (which are more education than research focused establishments). There was however only one HEl that had a genuinely positive story to tell regarding their experiences of HESD research 
and the REF. The university in question has a large educational research centre with a strong HESD theme, within which a range of academic staff work, research and publish collaboratively in HESDrelated research areas, as well as supporting other staff across their institution who are exploring sustainability education in a range of disciplines. In the 2014 REF exercise this university had been able to build a sufficiently strong narrative around their HESD research which was successfully submitted, along with other HE research, to the Education UoA.

\section{Discussion}

Overall the results of this analysis demonstrate that there is a perception amongst staff working in the field of HESD, that the UK's quality-related research funding system poses significant obstacles to the advancement of HESD research, insofar as staff feel discouraged by inherent pressures within the QR system from undertaking HESD research in the first place, and that even when HESD research is published, it cannot as readily be submitted and thus, rated and rewarded within the system. This experience and perception, spans the range of English university types and mission groups, as well as the broad range of job roles and academic disciplines represented in this study.

The results of this study do however suggest that staff working within (higher) education-focussed departments/research institutes may face fewer barriers and in addition, that some staff in New Universities, may perceive the barriers created by QR to be less of a problem, because of lesser pressures in terms of research outcomes. Several of these findings chime with recent similar studies, including: Sayer (2014) and Grove (2016) who have also detailed the systemic undermining of collegiality perpetuated by the REF; Cotton et al.'s (2017) findings that HE pedagogic researchers had been actively discouraged by heads of department from pursuing their supposedly 'lower status' pedagogic research; and the work of Marques et al. (2017), who analysed the increase over time in the proportion of QR submitted research in journal article format (rather than books, book chapters and other types of output), supporting the responses in this study that emphasized the culture of 'superior' 3* and 4* disciplinary journals. For those working in the field of HESD, the perception is that many of the pernicious characteristics of the REF descried by Elton over 15 years ago are very much still at play. Furthermore, this research reinforces key themes of critical environmental and sustainability education rhetoric about the 'neoliberal enemy' within global HE, serving as an entrenched obstacle to the progression of environmental and sustainability agendas, here specifically in terms of discouraging research into HESD.

Findings of this research appear to leave HESD research(ers) in a difficult quandary. Should we, as HESD researchers, seek, or even desire, to gain the research esteem bestowed by this elitist neoliberal system? Critically speaking, it is not hard to comprehend the ideological contradiction presented in seeking to tie HESD research agendas more closely to marketised regimes and instruments. It is also easy to argue that HESD research should be driven by the intrinsic, altruistic sustainability-based values of individual academics who want to 'educate for sustainability', not by the extrinsic, reputational drivers encouraged by the REF. As Sterling, Warwick and Wyness (2016, 89) have recently stated, '...for many ESD researchers, their primary purpose and motivation operates at a deeper level and relates to the grand challenges of securing a more sustainable societal and planetary future'. 
However, for the many researchers who continue with their HESD publications in spite of the barriers presented by $Q R$, but do desire for these outputs to be 'REF-able', the tangible barrier they face is how to transform their HESD research endeavours, from what may be perceived as an academic hobby activity, into one which is rewarded on par with their traditional disciplinary pursuits. Pragmatically speaking, if HESD research was more readily received and represented by the QR system, it is likely that this would lead to more engagement with environmental and sustainability-focused teaching and research across the board within English universities; a netpositive gain for the HESD field. So should we consign our HESD research to the backburner and bow to the disciplinary QR pressures, or are there more constructive ways to work with this marketised system? The remainder of this paper outlines four suggestions which may go some way towards enhancing the reputation and ultimately the REF-ability of HESD research in England.

\section{Forge connections with mainstream HE pedagogic research}

There is a large physical disconnect, with little overlap, between mainstream HESD research, e.g. published in journals such as Environmental Education Research, International Journal of Sustainability in Higher Education and Sustainability, amongst others, and mainstream HE pedagogic research, published in journals such as Studies in Higher Education, Higher Education Research \& Development and Higher Education Policy, with HESD literature often operating in its own silo away from the much broader and theoretically established field of HE research. A significant example of this insularity is the fact that HESD research(ers) have virtually no footprint whatsoever within the UK's largest and most prestigious HE research organisation, the Society for Research into Higher Education (SRHE) ${ }^{7}$. As an example, at the 2017 SRHE Annual Conference there were only two sustainability-focused papers out of over 300 papers in total at the event. HESD researchers should actively forge connections and explore synergies with the more mainstream HE literature, contemporary research themes in these areas, and national HE research communities of practice such as the SRHE, to broaden the reach and relevance of their research to different interest groups.

\section{Re-frame the 'sustainability' narrative}

Following from the above point, although HESD research is often published, disseminated and shared within HESD specific journals and research communities of practice, in theoretical terms, significant overlaps can be found between key themes of HESD research and the topics of research papers in mainstream HE research journals. Finding new approaches to frame the context of 'sustainability education', in ways which better align with these areas of research, may prove fruitful strategies for enhancing the REF-ability of HESD research. Indeed, despite a four-decade long history, environmental education and more recently education for sustainable development, remain specialist terms used largely by HESD advocates and enthusiasts. As Gough et al. $(2016,114)$ have recently written: '...much sustainable development education in higher education takes place in a partial or absolute ignorance of the existence of something called "Education for Sustainable Development"'. Might it be time for some considered, inward-looking reflection upon the language

\footnotetext{
${ }^{7}$ Society for Research into Higher Education (SRHE) is '... a UK-based international learned society concerned to advance understanding of higher education, especially through the insights, perspectives and knowledge offered by systematic research and scholarship (SRHE undated, 1).
} 
and framing of the HESD field, in order to, as Shephard (2015) suggests, help forge more common ground between those who advocate for HESD and those who do not?

\section{Improve the theoretical and methodological quality of HESD research}

A few interviewees within this study reflected upon the general quality of HESD research as an issue for its REF-ability, with several admitting that they felt ill-equipped in the research traditions of more mainstream HE pedagogical research fields. One interviewee talked about the difficulties faced in trying to 'recreate themselves as a social scientist' and another about how HESD research often falls on a 'fuzzy line between curriculum evaluation, publication and pedagogical research'; this echoes Cotton et al.'s (2017) description of HE pedagogic research falling in the 'borderland territory' between teaching and research. Indeed, issues surrounding the methodological and theoretical underpinnings of HESD research have been described several times in recent years (Corcoran, Walker and Wals 2004; Dillon and Wals, 2006; Barth and Rieckman, 2016; Kyburz-Graber 2016). More generally, Macfarlane (2011) has emphatically argued that 'soft funding' for HE teaching and learning projects, often leads to research outputs of low theoretical quality, which fail to draw upon substantial existing bodies of relevant literature. Universities wishing to produce REF-able HESD research may wish to think about strategies for more closely supporting researchers to develop strong theoretical and methodological underpinnings for their research, and to provide hands-on support for staff in navigating the field of leading HE and HESD publications, in order to help HESD researchers shift their outputs closer towards high-quality, internationally-recognised, peer reviewed journal articles.

\section{Create strategies and support systems for cross-university Education UoA submissions}

Of the seventy-seven HEls that submitted to REF Panel 25 (Education) in 2014, forty-seven of these were small submissions of fifteen or less Full Time Equivalent (FTE) staff (HEFCE 2015). This demonstrates that universities can be REF-able to this UoA with relatively small groups of staff. The development of research strategies and plans to support cross-university submissions to UoA 25, incorporating HESD as a key thematic area, would help to support HESD researchers working across different university departments and to position the REF-ability of HESD research going forward. The development of robust cross-university research networks and support structures within HEls to support HESD researchers would also help to raise the profile and visibility of these disparate researchers.

\section{Conclusion}

This paper has, for the first time, provided an empirical account of the experiences of academic staff in English universities engaged in HESD research and/or scholarship activities, in relation to the market-based pressures of the quality-related research funding system. Although some of the developments detailed in the introductory sections of this paper occurred post-data collection, and despite the slight time lag between data collection and publishing of this paper, all debates remain relevant and ongoing and all recommendations remain highly pertinent for HESD researchers. 
Results and thematic analysis of the thirty semi-structured interviews reveal a host of obstacles facing HESD researchers in terms of their own REF-ability, stemming from what is seen as, the elitist and disciplinary-focused nature of the QR system and a perceived systemic lack of recognition of interdisciplinary and pedagogical research within discipline-based UoAs, which has led to HESD researchers being actively discouraged from pursuing HESD and other pedagogical research by their university departments. Choosing whether to 'resist of reinforce' (Waitere et al. 2011) the QR regime, i.e. boycott or play to the discipline-based pressures, may be a difficult ideological and ethical choice for some. This paper has however, attempted to map out just a few strategies which may go some way in helping HESD researchers and scholars to be more fully respected and recognised by the QR system.

Sterling's transformative vision of 'sustainable education' - whereby sustainability sets the overarching context for all higher education policy priorities and fundamentally redesigns educational paradigms in a process of deep learning involving whole educational communities (Sterling 2001; 2004b) - feels a very long way away from the demands of the impending 2021 and 2025 REF exercises. Given that global sustainability (education) agendas remain imperative and pressing, HESD researchers have important choices to make about how to frame and strategically position their research narratives going forward. As one interviewee in this study lamented: 'Of all the great themes in education research, sustainability is not at the top table, in fact I'm not even sure it's in the room'. Perhaps the greatest task for HESD researchers over the next five to ten years is to constructively find their ways in to these established education research 'rooms', and this might mean breaking away from critical ideology to pursue pragmatic research ends; working with and within the marketised reality.

\section{References}

Adams, J. and Gurney, K. (2010) Funding selectivity, concentration and excellence - how good is the UK's research? Higher Education Policy Institute. [Online]. Available at:

http://www.hepi.ac.uk/2010/03/25/funding-selectivity-concentration-and-excellence-how-good-isthe-uks-research/ 
Alldred, P. and Miller, T. (2007) Measuring What's Valued or Valuing What's Measured? Knowledge Production and the Research Assessment Exercise. In: Gillies, V. and Lucey, H. (Eds.). Power, Knowledge and the Academy: The Institutional is Political. Palgrave: UK.

Arber, S. (2001). Designing Samples. In: Gilbert, N. (Ed.). Researching Social Life. Sage Publications: London.

Barker, K. (2007) The UK Research Assessment Exercise: the evolution of a national research evaluation system. Research Evaluation. 16: 1 (3-12).

Barth, M. and Rieckmann, M. (2016) State of the art in research on higher education for sustainable development. In: Barth, M., Michelsen, G., Rieckmann, M. and Thomas, I. (Eds.). Routledge Handbook of Higher Education for Sustainable Development. Routledge: Oxfordshire, UK.

Barth, M., Michelsen, G., Rieckmann, M. and Thomas, I. (2016) Introduction. In: Barth, M., Michelsen, G., Rieckmann, M. and Thomas, I. (Eds.). Routledge Handbook of Higher Education for Sustainable Development. Routledge: Oxfordshire, UK.

Bence, V. and Oppenheim, C. (2003) The role of academic journal publications in the UK Research Assessment Exercise. Learned Publishing. 17 (53-68).

Blewitt, J. (2012) Radicalizing Education for Sustainability. A Schumacher Institute Challenge Paper. [Online]. Available at: http://www.schumacherinstitute.org.uk/wpcontent/uploads/2015/04/Radicalising-Education-for-Sustainability-John-Blewitt.pdf

Brown, R. (2015) The Marketisation of Higher Education: Issues and Ironies. New Vistas. 1: 1 (4 - 9). [Online]. Available at: http://www.uwl.ac.uk/research/new-vistas-journal/volume-1-issue-1

Brown, R. and Carasso, H. (2013) Everything for Sale? The Marketisation of UK Higher Education. Society for Research into Higher Education: UK.

Cope, M. (2003) Coding Transcripts and Diaries. In: Clifford, N. and Valentine, G. (Eds.). Key Methods in Geography. SAGE: London.

Corcoran, P. B., Walker, K. E. and Wals, A.J. (2004) Case studies, make-your-case studies, and case stories: a critique of case-study methodology in sustainability in higher education. Environmental Education Research. 10: 1 (7-21).

Cotton, D., Miller, W. and Kneale, P. (2017) The Cinderella of academia: Is higher education pedagogic research undervalued in UK research assessment? Studies in Higher Education. http://www.tandfonline.com/doi/full/10.1080/03075079.2016.1276549

Crotty, M. (1998) The Foundations of Social Research: Meaning and Perspective in the Research Process. Sage Publications: London, UK.

della Porta, D. (2008) Comparative analysis: case oriented versus variable-oriented research. In: della Porta, D. and Keating, K. (Eds.) Approaches and Methodologies in the Social Sciences: A Pluralist Perspective. Cambridge University Press: New York. 
Dillon, J. and Wals, A. (2006) On the Danger of Blurring Methods, Methodologies and Ideologies in Environmental Education Research. Environmental Education Research. 12: 3 - 4 (549-558).

Elton, L. (2000) The UK Research Assessment Exercise: Unintended consequences. Higher Education Quarterly. 54: 3 (274-283).

Ferudi, F. (2011) Introduction to the marketisation of higher education and the student as consumer. In: Molesworth, M., Scullion, R. and Nixon, E. (Eds.). The Marketisation of Higher Education and the Student as Consumer. Routledge: UK.

Foskett, N. (2011) Markets, government, funding and the marketisation of UK higher education. In: Molesworth, M., Scullion, R. and Nixon, E. (Eds.). The Marketisation of Higher Education and the Student as Consumer. Routledge: UK.

Goldkuhl, G. (2012) Pragmatism vs interpretivism in qualitative information systems research. European Journal of Information Systems. 21: 2 (135 - 146).

Gonzalez-Gaudiano, E. J. (2016) ESD: Power, politics, and policy: "Tragic optimism" from Latin America. The Journal of Environmental Education. 47: 2 (118 - 127).

Gough, S., Mor, M., Sowter, A. and Vare, P. (2016) Ongoing and future directions of research on higher education for sustainable development. In: Barth, M., Michelsen, G., Rieckmann, M. and Thomas, I. (Eds.). Routledge Handbook of Higher Education for Sustainable Development. Routledge: Oxfordshire, UK.

Grove, J. (2016) Does the REF Motivate or Discourage Research Staff? Times Higher Education. Online. Available at: https://www.timeshighereducation.com/news/does-ref-motivate-ordiscourage-research-staff

Harland, T., Tidswell, T., Everett, D., Hale, L. and Pickering, N. (2010) Neoliberalism and the academic as critic and conscience of society. Teaching in Higher Education. 15: 1 (85-96).

Harley, S. (2002) The impact of research selectivity on academic work and identity in UK universities. Studies in Higher Education. 27: 2 (187-203).

HEFCE (2015) Research Excellence Framework 2014: Overview report by Main Panel C and Subpanels 16 to 26. Higher Education Funding Council for England. [Online]. Available at:

http://www.ref.ac.uk/media/ref/content/expanel/member/Main\%20Panel\%20C\%20overview\%20re port.pdf

HEFCE (2016) REF Impact. Higher Education Funding Council for England. [Online]. Available at: http://www.hefce.ac.uk/rsrch/REFimpact/

Hursh, D. Henderson, J. and Greenwood, D. (2015) Editorial: Environmental Education in a Neoliberal Climate. Environmental Education Research. 21: 3 (299 - 318).

Irwin, R. (2007) 'After Neoliberalism': Environmental Education to Education for Sustainability. Conference Presentation: Philosophy of Education Society of Australasia. [Online]. Available at: 
http://www.academia.edu/3123057/After Neoliberalism Environmental Education to Education for Sustainability

Kneale, P., Cotton, D. and Miller, W. (2016) Higher education pedagogic research and impact. Higher Education Academy. [Online]. Available at: https://www.heacademy.ac.uk/knowledge-hub/ref-2014higher-education-pedagogic-research-and-impact

Kogan, M. and Hanney, S. (2000) Reforming Higher Education. Jessica Kingsley Publishers: UK.

Kopnina, H. (2016) Of big hegemonies and little tigers: Ecocentrism and environmental justice. The Journal of Environmental Education. 47: 2 (139-150).

Kyburz-Graber, R. (2016) Case Study Research on Higher Education for Sustainable Development: Epistemological foundation and quality challenges. In: Barth, M., Michelsen, G., Rieckmann, M. and Thomas, I. (Eds.). Routledge Handbook of Higher Education for Sustainable Development. Routledge: Oxfordshire, UK.

Lohse, S. (2017) Pragmatism, Ontology, and Philosophy of the Social Sciences in Practice. Philosophy of the Social Sciences. 47: 1 (3-27).

Lotz-Sisitka, H. (2016) A Review of Three Generations of Critical Theory: Towards conceptualising critical HESD research. In: Barth, M., Michelsen, G., Rieckmann, M. and Thomas, I. (Eds.). Routledge Handbook of Higher Education for Sustainable Development. Routledge: Oxfordshire, UK.

Lucas, L. (2006) The Research Game in Academic Life. SRHE/Open University Press: Maidenhead, UK.

Macfarlane, B. (2011) Prizes, pedagogic research and teaching professors: lowering the status of teaching and learning through bifurcation. Teaching in Higher Education. 16: 1 (127 - 130).

Marques, M., Powell, J., Zapp, M. and Biesta, G. (2017) How does research evaluation impact educational research? Exploring intended and unintended consequences of research assessment in the United Kingdom, 1986-2014. European Educational Research Journal. 16: 6 (820 - 842).

McArthur, J. (2011). Reconsidering the social and economic purposes of higher education. Higher Education Research \& Development. 30: 6 (737-749).

McCaig, C. (2011) Trajectories of higher education system differentiation: structural policymaking and the impact of tuition fees in England and Australia. Journal of education and work. 24: 1 - 2 (725).

McKenzie, M. (2012) Education for Y'all: global neoliberalism and the case for a politics of scale in sustainability education policy. Policy Futures in Education. 10: 2 (165 - 177).

McNay, I. (2003) Assessing the assessment: An analysis of the UK Research Assessment Exercise, with special reference to research in education. Science and Public Policy. 30: 1 (47 - 54).

McNay, I. (2015) Debate: Does research quality assessment increase output and give value for money. Public Money and Management. 35: 1 (67-68). 
Morgan, D. (2014) Pragmatism as a paradigm for social research. Qualitative Inquiry. 20 (1045 1053).

Newman, M. (2009) Do you want to be in my gang? Times Higher Education. [Online]. Available at: https://www.timeshighereducation.com/features/do-you-want-to-be-in-my-gang/409118.article

Oancea, A. (2010) The BERA/UCET Review of the Impacts of RAE 2008 on Education Research in UK Higher Education Institutions. Universities' Council for the Education of Teachers / British Educational Research Association: Macclesfield, UK.

Oancea, A. (2014) Research assessment as governance technology in the United Kingdom: findings from a survey of RAE 2008 impacts. Zeitschrift für Erziehungswissenschaft. 17: S6 (83 - 110).

OfS (2018) What we do. Office for Students. [Online]. Available at:

https://www.officeforstudents.org.uk/

Olssen, M. and Peters, M. A. (2005) Neoliberalism, higher education and the knowledge economy: from the free market to knowledge capitalism. Journal of Education Policy. 20: 3 (313-345).

People and Planet (2013) People and Planet Green League Guide 2013. [Online]. Available at: http://peopleandplanet.org/dl/greenleague/2013/guide-print-version.pdf

QAA (2014) Education for sustainable development: Guidance for UK higher education providers. Quality Assurance Agency. [Online]. Available at:

http://www.qaa.ac.uk/en/Publications/Documents/Education-sustainable-development-GuidanceJune-14.pdf

QS World University Rankings (2016) QS World University Rankings 2015/16. [Online]. Available at: http://www.topuniversities.com/qs-world-university-rankings

Ross, N. (2012) University mission groups explained. Brightside Bright Knowledge. [Online] Available at: http://www.brightknowledge.org/knowledge-bank/bright-voices/bright-voices-2012/natashaross/university-mission-groups-explained

Russell Group (2015) About. Russel Group. [Online]. Available at: http://russellgroup.ac.uk/about/

Saldana, J. (2009) The Coding Manual for Qualitative Researchers. Sage: London.

Sayer, D. (2014) Five reasons why the REF is not fit for purpose. The Guardian. [Online]. Available at: https://www.theguardian.com/higher-education-network/2014/dec/15/research-excellenceframework-five-reasons-not-fit-for-purpose

Scott, P. (2013) University mission groups: what are they good for? The Guardian. [Online]. Available at: http://www.theguardian.com/education/2013/mar/04/university-mission-groups-comment

Shephard, K. (2015) Higher Education for Sustainable Development. Palgrave Macmillan: UK.

Simons, H. (2009) Case Study Research in Practice. Sage Publishing: UK. 
SRHE (undated) About us. Society for Research into Higher Education. [Online]. Available at: https://www.srhe.ac.uk/about us/

Sterling, S. (2001) Sustainable Education: Re-visioning Learning and Change. Schumacher Briefings. Green Books: Devon, UK.

Sterling, S. (2004a) Higher education, sustainability and the role of systemic learning. In: Corcoran, P. B. and Wals, A. E. J. (Eds.). Higher Education and the Challenge of Sustainability: Problematics, Promise and Practice. Kluwer Academic Publishers: Netherlands.

Sterling, S. (2004b) An Analysis of the Development of Sustainability Education Internationally: Evolution, Interpretation and Transformative Potential. In: Blewitt, J. and Cullingford, C. (Eds.). The Sustainability Curriculum: The Challenge for Higher Education. Earthscan: London, UK.

Sterling, S., Warwick, P. and Wyness, L. (2016) Understanding approaches to ESD research on teaching and learning in higher education. In: Barth, M., Michelsen, G., Rieckmann, M. and Thomas, I. (Eds.). Routledge Handbook of Higher Education for Sustainable Development. Routledge: Oxfordshire, UK.

Tysome, T. (2007) Former polytechnics spread their wings. Times Higher Education. [Online]. Available at: https://www.timeshighereducation.com/news/former-polytechnics-spread-theirwings/310328.article

UUK (2016) University Funding Explained. Universities UK. [Online]. Available at: https://www.universitiesuk.ac.uk/university-funding-explained

Waitere, H.J., Wright, J., Tremaine, M., Brown, S. and Pausé, C. (2011) Choosing whether to resist or reinforce the new managerialism: the impact of performance-based research funding on academic identity. Higher Education Research \& Development. 30: 2 (205 - 217).

Watermeyer, R. (2016) Impact in the REF: issues and obstacles. Studies in Higher Education. 41: 2 (199-214).

West, C. (1989) The American Evasion of Philosophy: A Genealogy of Pragmatism. University of Wisconsin Press: US.

Williams, G. (1995) The 'marketisation' of higher education: reforms and potential reforms in higher education finance. In: Dill, D. and Sporn, B. (Eds.). Emerging Patterns of Social Demand and University Reform: Through a Glass Darkly. Pergamon Press: Oxford.

Williams, G. (1997) The market route to mass higher education: British experience 1979 - 1996. Higher Education Policy. 10: 3/4 (275-289).

Williams, G. (2016) Higher education: Public good or private commodity? London Review of Education. 14: 1 (131-142).

Yin, R. K. (2003) Case Study Research: Design and Methods. 3rd Edition. Sage Publications: California. 


\section{Appendix}

\section{Table 1 - Four principle HEI categories in English higher education}

\section{Russell Group Universities}

- 24 universities (20 in England)

- $\quad$ The prestigious Russell Group of universities was formed in 1994 and represents 24 leading research intensive UK universities which are committed to maintaining the highest quality research, outstanding teaching and learning experience for students and unrivalled links with business and the public sector.

- Generally, Russell Group universities are the oldest and most prestigious and expect the highest entry requirements from students.

- The Russell Group universities have a total economic output of over $£ 32$ billion per annum - $44 \%$ of the total economic output for the whole UK university sector (of which Russell Group universities comprise just 15\%).

- The proportion of world leading research at Russell Group universities is almost double that at other universities.

- $\quad$ Russell group universities are also recognised as world-leaders. In the 2015 QS World University Rankings, the Russell Group had four of the top ten universities in the world, 17 in the Top 100 and all 24 in the Top 190.

\section{Research Led and 1994 Group Universities}

- The 1994 Group was a coalition of highly rated but smaller research intensive universities in the UK. The group disbanded in 2013.

- Membership changed over the years but in total there were 22 universities part of the group (21 in England).

- The group was founded in 1994 to defend their interests following the creation of the Russell Group by larger research intensive universities earlier that year.

- Overall, the group can be seen as second to the Russell Group in terms of prestige and entry requirements for students.

- $\quad$ Research Led HEls are universities which were not formally part of the 1994 Group but who are research led in their approach (approximately $10-15$ universities).

\section{Former Polytechnic Universities}

- Polytechnics and colleges of higher education (often grouped together as the 'former polytechnics') were UK HEIs, which up until 1992 were funded by local authorities and had their degrees externally validated by the Council for National Academic Awards (CNAA) or by neighbouring universities.

- After the passage of the Further and Higher Education Act in 1992 the polytechnics became independent universities.

- The former polytechnics had a history of teaching technical and vocational education, although this has significantly expanded into more traditional academic areas since 1992.

- Many former polytechnics have also advanced their research focus since 1992.

- Overall, the former polytechnic universities are not as research focused as the Russell Group, 1994 Group or Research Led HEls.

- $\quad$ There are 31 universities in England which are Former Polytechnics.

\section{New Universities}

- $\quad$ After the former polytechnic universities were granted university status in 1992 there was a lull before a second wave of institutions were granted university status after the year 2000 .

- $\quad$ These $21^{\text {st }}$ century institutions are often called 'new' or 'modern' universities.

- The New Universities have a variety of histories but are overall more teaching focused than research focused.

\section{References}

Williams, 1997; Tysome, 2007, 1; Newman, 2009, 1; Ross, 2012, 1; Scott, 2013, 1; QS World University Rankings, 2016, 1; Russell Group, 2015, 1 
Table to be included in text

Table 2 - Number of interviewees by professional category, academic title and institution type represented in this paper

\begin{tabular}{|c|c|c|c|}
\hline \multicolumn{3}{|c|}{ Professional Category + Explanation } & $\begin{array}{l}\text { Number of } \\
\text { Interviewees }\end{array}$ \\
\hline \multicolumn{3}{|c|}{ 1. Heads/Directors of ESD: Dedicated full-time positions } & 1 \\
\hline \multicolumn{3}{|c|}{$\begin{array}{l}\text { 2. University ESD Leads: Full-time academic staff from a variety of disciplines } \\
\text { with part-time ESD roles (some with official role titles, some without; some with } \\
\text { fractional time bought out of full-time contracted hours, some without time } \\
\text { bought out) }\end{array}$} & 7 \\
\hline \multicolumn{3}{|c|}{$\begin{array}{l}\text { 3. Senior University Staff: Pro-Vice Chancellors, Faculty Deans, Heads of } \\
\text { Educational/Academic Development/Quality }\end{array}$} & 4 \\
\hline \multicolumn{3}{|c|}{$\begin{array}{l}\text { 4. Academics from sustainability-related disciplines: e.g. Geography, Climate } \\
\text { Studies, Environmental Science and Sustainability }\end{array}$} & 6 \\
\hline \multicolumn{3}{|c|}{$\begin{array}{l}\text { 5. Academics from disciplines with strong links to sustainability: e.g. } \\
\text { Engineering, Politics, Business, Management, Biology and Community Studies }\end{array}$} & 6 \\
\hline \multicolumn{3}{|c|}{$\begin{array}{l}\text { 6. Academics from disciplines not traditionally related to sustainability: e.g. } \\
\text { English Literature, Chemistry, Economics, Ancient History and Health Studies }\end{array}$} & 6 \\
\hline Academic Title & $\begin{array}{l}\text { Number of } \\
\text { Interviewees }\end{array}$ & Institution Type & $\begin{array}{l}\text { Number of } \\
\text { Interviewees }\end{array}$ \\
\hline Professor & 10 & Russell Group & 6 \\
\hline Associate Professor & 1 & Research Led & 10 \\
\hline Emeritus Professor & 1 & Former Polytechnic & 9 \\
\hline Reader & 3 & New Universities & 5 \\
\hline Senior Lecturer & 6 & & \\
\hline Principal Lecturer & 1 & & \\
\hline Lecturer & 5 & & \\
\hline Senior Teaching Fellow & 1 & & \\
\hline Other & 2 & & \\
\hline
\end{tabular}


Figure to be included in text

CONTEXT: Marketisation in English HE

CASE STUDY: HESD agenda in English HE Higher education bodies and organisations with a sustainability/ESD remit and sustainability/ESDactive staff.
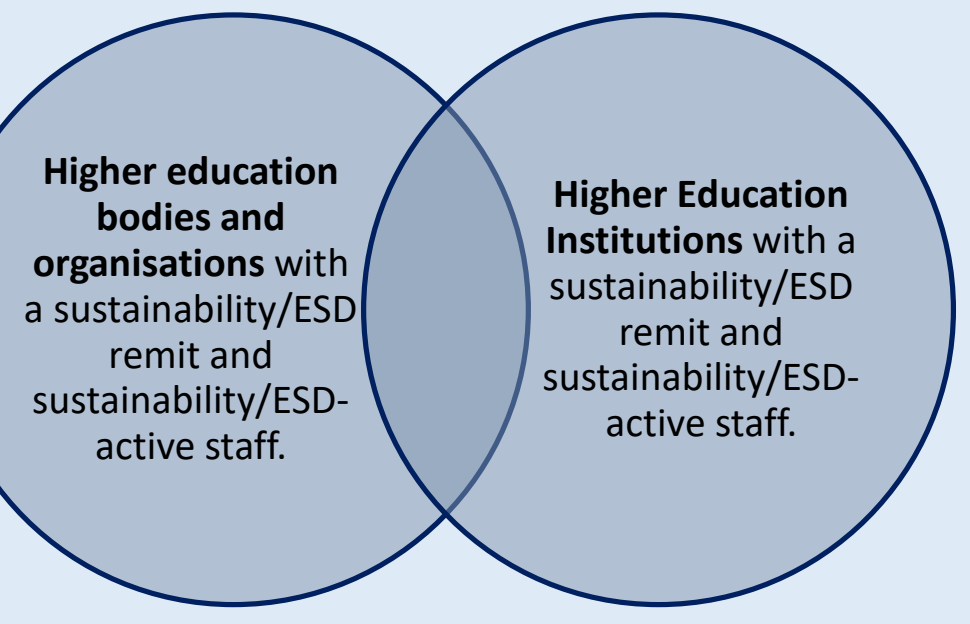

Figure 1 - Conceptualisation of the doctoral case study research design 